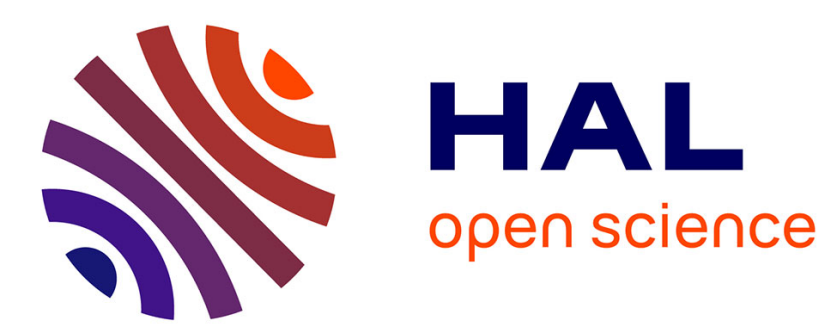

\title{
Power factor correction of an electrical drive system based on multiphase machines
}

Khoudir Marouani, Kamel Nounou, Mohamed Benbouzid, Bekheira Tabbache

\section{To cite this version:}

Khoudir Marouani, Kamel Nounou, Mohamed Benbouzid, Bekheira Tabbache. Power factor correction of an electrical drive system based on multiphase machines. IEEE ICGE 2014, Mar 2014, Sfax, Tunisia. pp.152-157. hal-01023507

\section{HAL Id: hal-01023507 https://hal.science/hal-01023507}

Submitted on 13 Jul 2014

HAL is a multi-disciplinary open access archive for the deposit and dissemination of scientific research documents, whether they are published or not. The documents may come from teaching and research institutions in France or abroad, or from public or private research centers.
L'archive ouverte pluridisciplinaire HAL, est destinée au dépôt et à la diffusion de documents scientifiques de niveau recherche, publiés ou non, émanant des établissements d'enseignement et de recherche français ou étrangers, des laboratoires publics ou privés. 


\section{Power factor correction of an electrical drive system based on multiphase machines}

\author{
Khoudir MAROUANI \\ Ecole Militaire Polytechnique \\ LCM-UER-ELT \\ Bordj El-Bahri-16046, \\ Algiers, Algeria \\ marouani_khoudir@yahoo.fr
}

\author{
Kamel NOUNOU \\ Ecole Militaire Polytechnique \\ LCM-UER-ELT \\ Bordj El-Bahri-16046, \\ Algiers, Algeria
}

\author{
Mohamed BENBOUZID \\ University of Brest, EA 4325 \\ LBMS, Rue de Kergoat, CS \\ 93837, 29238 Brest Cedex 03, \\ France \\ Mohamed.Benbouzid@univ-brest.fr
}

\author{
Bekheïra TABBACHE \\ Ecole Militaire Polytechnique \\ LCM-UER-ELT \\ Bordj El-Bahri-16046, \\ Algiers, Algeria \\ laid_tabache@yahoo.com
}

\begin{abstract}
This paper deals with the energy efficiency improvement of an electrical drive which can be used both in wind energy conversion or motor drive applications. A power factor (PF) control scheme is presented allowing energy efficiency enhancement and optimization in high power variable-speed drives based on multiphase machines. Thus, the double-star induction machine is taken, as an example of multiphase machines, to introduce the principle of the study presented in this paper. In fact, the purpose of this paper is to maintain the PF of the power-winding, of the double star induction machine, in vicinity of unity whatever the drive operating point. Also, this control scheme can be generalized for several kinds of multiphase machines.
\end{abstract}

Keywords - Double fed induction machine; energy efficiency; multiphase machine; power factor control (PFC).

\section{INTRODUCTION}

Nowadays, a great interest for multiphase electrical machines is in progress, both for renewable energy applications or energy electromechanical conversion. Multiphase machine signify a machine with more than three phases in the stator side. So, the number of phases can be used as an additional degree of freedom to improve reliability, efficiency and optimization of the overall system. Such improvements can be easily demonstrated considering the torque ripples reduction, power segmentation and fault-tolerance capability [1-3].

As most of drive systems are dedicated to variable-speed and variable-load operations, this leads to operating point variation and consequently to $\mathrm{PF}$ variation. It is shown in several works that switching losses in static converters are PF depending in case of use of the so called discontinuous PWM techniques (DPWM) [4-7]. So, the switching losses can be significantly reduced using DPWM techniques at high PF values and this contributes strongly to energy efficiency improvement. Moreover in high power applications, having low converter losses is essential to maintain thermal limits.

This paper proposes an improved power factor $(\mathrm{PF})$ control scheme in high power variable-speed drives based on multiphase machines. This control scheme is inspired from that of the double-fed induction machine where both stator and rotor are fed by static inverters in order to compensate reactive power and therefore ensure a unity power factor operation [8], [9]. Moreover, this scheme can be used in case of generator or motor operations and generalized for all kinds of multiphase machines.
An example of a multiphase machine is multi-star machine and particularly the double star induction machine (DSIM). Thus, the DSIM is taken as an example to introduce the principle of the study presented in this paper. So, the first star can be used as control winding $(\mathrm{CW})$ to compensate the reactive power while the second one acts as power winding (PW) which provides the necessary active power, as shown in Fig. 1. Hence, the purpose of this paper is to maintain the PF of the power-winding, of the double star induction machine, in vicinity of unity whatever the drive operating point, allowing DPWM techniques selection. Also, this control scheme can be generalized for several kinds of multiphase machines.

\section{SYSTEM DESCRIPTION}

The system is composed of a DSIM, where its two sets of three-phase windings share the same stator magnetic core and spatially phase shifted by 30 electrical degrees. Also, the two sets are identical and symmetrical with the two neutrals being isolated. Each set of stator winding is fed by a three-phase voltage source inverter (VSI). The rotor is identical to that of a three-phase squirrel cage induction machine. Depending on the control strategy, the DSIM can be considered as an asymmetrical six-phase machine, and therefore the Park model is obtained by applying an appropriate transformation matrix which leads to three sub-models completely decoupled [2], [10]. In this paper the DSIM is considered as the combination of two three-phase machines sharing the same magnetic circuit and the usual Park transformation is applied for each threephase set [11].

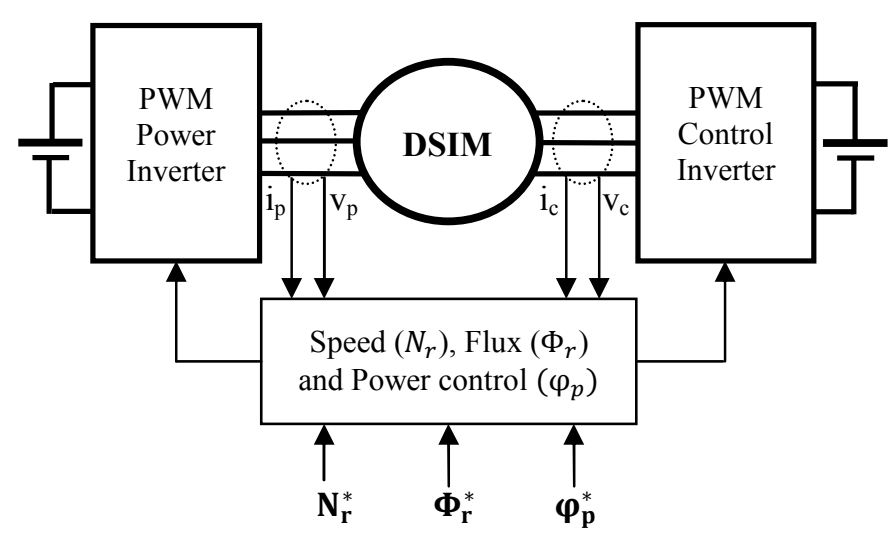

Fig. 1. DSIM PF control principle scheme. 


\section{MACHINE MODELING}

Based on the usual simplification assumptions and considering the DSIM as the combination of two three-phase machines sharing the same magnetic circuit, the usual Park transformation is applied for each three-phase winding. Thus, the DSIM model is decomposed into two main sub-models noted $\left(\mathrm{ds}_{1}-\mathrm{qs}_{1}\right)$ and $\left(\mathrm{ds}_{2}-\mathrm{qs}_{2}\right)$ for the stator side and one submodel noted (dr-qr) for the rotor side. All sub-models are expressed in the synchronous reference frame.

The stator voltage sub-model $\left(\mathrm{ds}_{1}-\mathrm{qs}_{1}\right)$ is written as:

$\left\{\begin{array}{l}V_{s d 1}=R_{s} I_{s d 1}+\frac{d \phi_{s d 1}}{d t}-\omega_{s} \phi_{s q 1} \\ V_{s q 1}=R_{s} I_{s q 1}+\frac{d \phi_{s q 1}}{d t}+\omega_{s} \phi_{s d 1}\end{array}\right.$

The stator voltage sub-model $\left(\mathrm{ds}_{2}-\mathrm{qs}_{2}\right)$ is written as:

$\left\{\begin{array}{l}V_{s d 2}=R_{s} I_{s d 2}+\frac{d \phi_{s d 2}}{d t}-\omega_{s} \phi_{s q 2} \\ V_{s q 2}=R_{s} I_{s q 2}+\frac{d \phi_{s q 2}}{d t}+\omega_{s} \phi_{s d 2}\end{array}\right.$

The rotor voltage sub-model (dr-qr) is written as:

$\left\{\begin{array}{l}V_{r d}=0=R_{r} I_{r d}+\frac{d \phi_{r d}}{d t}-\omega_{r} \phi_{r q} \\ V_{r q}=0=R_{r} I_{r q}+\frac{d \phi_{r q}}{d t}+\omega_{r} \phi_{r d}\end{array}\right.$

The flux equations can be written as:

$$
\begin{array}{r}
\left\{\begin{array}{l}
\phi_{s d 1}=L_{s} I_{s d 1}+L_{m s} I_{s d 2}+M I_{r d} \\
\phi_{s q 1}=L_{s} I_{s q 1}+L_{m s} I_{s q 2}+M I_{r q}
\end{array}\right. \\
\left\{\begin{array}{l}
\phi_{s d 2}=L_{s} I_{s d 2}+L_{m s} I_{s d 1}+M I_{r d} \\
\phi_{s q 2}=L_{s} I_{s q 2}+L_{m s} I_{s q 1}+M I_{r q}
\end{array}\right. \\
\left\{\begin{array}{l}
\phi_{r d}=L_{r} I_{r d}+M\left(I_{s d 1}+I_{s d 2}\right) \\
\phi_{r q}=L_{r} I_{r q}+M\left(I_{s q 1}+I_{s q 2}\right)
\end{array}\right.
\end{array}
$$

The electromagnetic torque is as following:

$T_{e}=p \frac{M}{L_{r}}\left[\phi_{r d}\left(I_{s q 1}+I_{s q 2}\right)-\phi_{r q}\left(I_{s d 1}+I_{s d 2}\right)\right]$

Because the two star's neutrals are isolated, the traditional homopolar components are neglected. All machine's parameters are defined in the appendix.

If the voltage equations (1), (2) and (3) of the DSIM are examined, they look-like those of two separate three-phase machines. But, the flux equations (4), (5) and (6) present coupling terms, because the two three-phase windings share the same magnetic circuit. In spite of these coupling terms, the control of the DSIM can be done exactly as the case of the three-phase machine.

\section{DRIVE CONTROL}

In this section the indirect field oriented control (IFOC) technique applied to the DSIM is presented firstly and then the proposed PF control scheme, based on IFOC principle, will be detailed.
In case of rotor flux orientation, its components are controlled to ensure the following condition:

$\left\{\begin{array}{l}\phi_{r q}=0 \\ \phi_{r d}=\phi_{r}\end{array}\right.$

The DSIM control can be ensured via the stator current components by substituting (8) in (6) and eliminating the rotor current components from (4) and (5). This leads to the following flux expressions:

$\left\{\begin{array}{l}\phi_{s d 1}=\sigma_{1} L_{s} I_{s d 1}+\sigma_{2} L_{m s} I_{s d 2}+\frac{M}{L_{r}} \phi_{r} \\ \phi_{s q 1}=\sigma_{1} L_{s} I_{s q 1}+\sigma_{2} L_{m s} I_{s q 2}\end{array}\right.$

$\left\{\begin{array}{l}\phi_{s d 2}=\sigma_{1} L_{s} I_{s d 2}+\sigma_{2} L_{m s} I_{s d 1}+\frac{M}{L_{r}} \phi_{r} \\ \phi_{s q 2}=\sigma_{1} L_{s} I_{s q 2}+\sigma_{2} L_{m s} I_{s q 1}\end{array}\right.$

$\left\{\begin{array}{l}I_{r d}=\frac{1}{L_{r}}\left(\phi_{r}-M\left(I_{s d 1}+I_{s d 2}\right)\right) \\ I_{r q}=-\frac{M}{L_{r}}\left(I_{s q 1}+I_{s q 2}\right)\end{array}\right.$

With : $\sigma_{1}=1-\frac{M^{2}}{L_{s} L_{r}} ; \sigma_{2}=1-\frac{M^{2}}{L_{m s} L_{r}} ; \mathrm{T}_{\mathrm{r}}=\frac{R_{r}}{L_{r}}$

Substituting (9), (10) and (11) in stator and rotor voltage equations (1), (2) and (3) provides the main expressions as following:

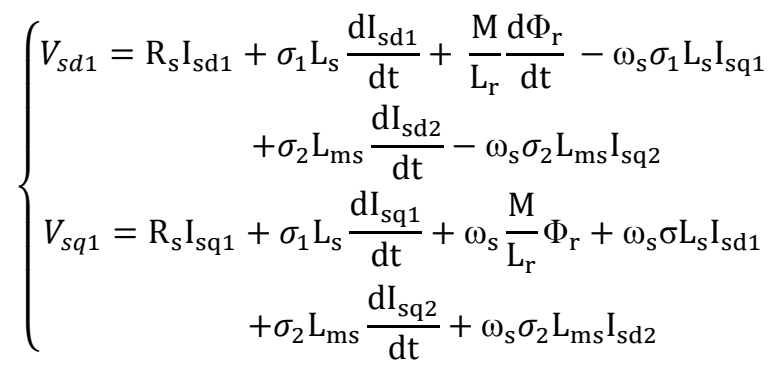

$\left\{\begin{aligned} V_{s d 2}=\mathrm{R}_{\mathrm{s}} \mathrm{I}_{\mathrm{sd} 2} & +\sigma_{1} \mathrm{~L}_{\mathrm{s}} \frac{\mathrm{dI} \mathrm{I}_{\mathrm{sd} 2}}{\mathrm{dt}}+\frac{\mathrm{M}}{\mathrm{L}_{\mathrm{r}}} \frac{\mathrm{d} \Phi_{\mathrm{r}}}{\mathrm{dt}}-\omega_{\mathrm{s}} \sigma_{1} \mathrm{~L}_{\mathrm{s}} \mathrm{I}_{\mathrm{sq} 2} \\ & +\sigma_{2} \mathrm{~L}_{\mathrm{ms}} \frac{\mathrm{dI} \mathrm{sd}_{1}}{\mathrm{dt}}-\omega_{\mathrm{s}} \sigma_{2} \mathrm{~L}_{\mathrm{ms}} \mathrm{I}_{\mathrm{sq} 1} \\ V_{s q 2}=\mathrm{R}_{\mathrm{s}} \mathrm{I}_{\mathrm{sq} 2} & +\sigma_{1} \mathrm{~L}_{\mathrm{s}} \frac{\mathrm{dI} \mathrm{sq}_{2}}{\mathrm{dt}}+\omega_{\mathrm{s}} \frac{\mathrm{M}}{\mathrm{L}_{\mathrm{r}}} \Phi_{\mathrm{r}}+\omega_{\mathrm{s}} \sigma \mathrm{L}_{\mathrm{s}} \mathrm{I}_{\mathrm{sd} 2} \\ & +\sigma_{2} \mathrm{~L}_{\mathrm{ms}} \frac{\mathrm{dI} \mathrm{sq} 1}{\mathrm{dt}}+\omega_{\mathrm{s}} \sigma_{2} \mathrm{~L}_{\mathrm{ms}} \mathrm{I}_{\mathrm{sd} 1}\end{aligned}\right.$

$\left\{\begin{array}{c}M\left(I_{s d 1}+I_{s d 2}\right)=\Phi_{\mathrm{r}}+\mathrm{T}_{\mathrm{r}} \frac{\mathrm{d} \Phi_{\mathrm{r}}}{\mathrm{dt}} \\ \omega_{\mathrm{r}}=\frac{\left(I_{s q 1}+I_{s q 2}\right)}{\mathrm{T}_{\mathrm{r}}\left(I_{s d 1}+I_{s d 2}\right)}\end{array}\right.$

Taking into account the steady state operation, the rotor flux can be written as following:

$\Phi_{\mathrm{r}}=\mathrm{M}\left(I_{s d 1}+I_{s d 2}\right)$

Also, the torque equation (7) becomes: 


$$
\mathrm{T}_{\mathrm{e}}=p \frac{\mathrm{M}}{\mathrm{L}_{\mathrm{r}}} \Phi_{\mathrm{r}}\left(I_{s q 1}+I_{s q 2}\right)
$$

Expressions (14) and (15) demonstrate the principle of IFOC control of DSIM and allow PF control as shown in next section.

\section{POWER FACTOR CORRECTION}

While, the purpose of this paper is to maintain the PF in vicinity of unity whatever the drive operating point, this section exposes the principle of the proposed PF control technique. So, based on the IFOC scheme the simplest way to ensure a PF correction is to impose the following condition:

$I_{s d 2}=I_{s q 1}=0$

Equations (13), (14) and (15) become as follows:

$$
\left\{\begin{array}{l}
\Phi_{\mathrm{r}}=M I_{s d 1} \\
\mathrm{~T}_{\mathrm{e}}=p \frac{\mathrm{M}}{\mathrm{L}_{\mathrm{r}}} \Phi_{\mathrm{r}} I_{s q 2} \\
\omega_{\mathrm{r}}=\frac{I_{s q 2}}{\mathrm{~T}_{\mathrm{r}} I_{s d 1}}
\end{array}\right.
$$

Equation (17) shows that the rotor flux can be controlled by $I_{s d 1}$ current component which provides the required magnetizing reactive power, and the torque can be controlled by $I_{s q 2}$ component as well the active power. The active and reactive powers are given as follows:

$\left\{\begin{array}{l}P_{s 1}=\mathrm{V}_{\mathrm{sd} 1} \mathrm{I}_{\mathrm{sd} 1}+\mathrm{V}_{\mathrm{sq} 1} \mathrm{I}_{\mathrm{sq} 1} \\ Q_{s 1}=\mathrm{V}_{\mathrm{sq} 1} \mathrm{I}_{\mathrm{sd} 1}-\mathrm{V}_{\mathrm{sd} 1} \mathrm{I}_{\mathrm{sq} 1}\end{array}\right.$
$\left\{\begin{array}{l}P_{s 2}=\mathrm{V}_{\mathrm{sd} 2} \mathrm{I}_{\mathrm{sd} 2}+\mathrm{V}_{\mathrm{sq} 2} \mathrm{I}_{\mathrm{sq} 2} \\ Q_{s 2}=\mathrm{V}_{\mathrm{sq} 2} \mathrm{I}_{\mathrm{sd} 2}-\mathrm{V}_{\mathrm{sd} 2} \mathrm{I}_{\mathrm{sq} 2}\end{array}\right.$

According to (16) the relations (18) and (19) become:

$\left\{P_{s 1}=\mathrm{V}_{\mathrm{sd} 1} \mathrm{I}_{\mathrm{sd} 1}\right.$

$\left\{Q_{s 1}=\mathrm{V}_{\mathrm{sq} 1} \mathrm{I}_{\mathrm{sd} 1}\right.$

$P_{s 2}=\mathrm{V}_{\mathrm{sq} 2} \mathrm{I}_{\mathrm{sq} 2}$

$\left\{Q_{s 2}=-\mathrm{V}_{\mathrm{sd} 2} \mathrm{I}_{\mathrm{sq} 2}\right.$

Expressions (20) and (21) show that also active and reactive powers can be controlled by $I_{s d 1}$ and $I_{s q 2}$ current components, as for rotor flux and torque.

In addition, the stator current components $I_{s q 1}$ and $I_{s d 2}$ offer another degree of freedom for more system control. Thus, based on the powers relations (18) and (19) the new current references $I_{s d 2}$ and $I_{s q 1}$ that allowing the cancellation of $Q_{s 2}$ and $P_{s 1}$ are as following:

$$
\left\{\begin{array}{c}
I_{s q 1}=-\frac{V_{s d 1} I_{s d 1}}{V_{s q 1}} \\
I_{s d 2}=\frac{V_{s d 2} I_{s q 2}}{V_{s q 2}}
\end{array}\right.
$$

Based on (22), PF control scheme can be chosen based on $\mathrm{PF}$ reference, as well a power control technique as DPC (Direct Power Control) can be implemented. While the aim of this paper is only to introduce the possibility of PF control principle in multiphase machines under IFOC, proper power control techniques are under studies and will be reported in a subsequent paper.

\section{SimULATION RESULTS}

In order to demonstrate the effectiveness of the proposed scheme (Fig.1), some tests under IFOC are performed for both cases with and without PF control at the same conditions. Also, the simulation results presented in this section concern only the steady state operation. Thus, initially the motor is running at $716 \mathrm{rpm}$ corresponding to its rated speed without a load torque, and then low load torques of $5 \mathrm{Nm}$ and $10 \mathrm{Nm}$ are applied at instants $\mathrm{t}=0.3 \mathrm{~s}$ and $\mathrm{t}=0.5 \mathrm{~s}$ respectively as shown in Fig. 2 (the traced torque is multiplied by a coefficient equal 20 , for purpose of presentation). These load torque values are selected in order to allow a low PF operation. Also, in the next sections a detailed comparison focuses only on the operating point corresponding to the lowest $\mathrm{PF}$ value under a load torque of $5 \mathrm{Nm}$.

\section{a) IFOC of DSIM}

The main simulation results corresponding to normal operation of the DSIM under IFOC, where the two stator winding sets provide equal powers, are shown in Fig. 3. Accordingly for the operating point corresponding to load torque of $5 \mathrm{Nm}$, the rotor flux and speed (torque) control loops lead to $I_{s d 1}=I_{s d 2}=3 \mathrm{~A}$ corresponding to the nominal flux, and $I_{s q 1}=I_{s q 2}=1.65 \mathrm{~A}$ equivalent to the load torque, as shown in Fig. 3-(a) and (b). As a result, the active powers are $P_{s 1}=P_{s 2}=225 \mathrm{~W}$ as well the reactive powers are $Q_{s 1}=$ $Q_{s 2}=885 \mathrm{VAR}$, as shown in Fig. 3-(c). Hence, the corresponding PF value is low and equal to 0.25 (Fig. 3-(d)), equivalent to a load angle of $\varphi_{s 1}=\varphi_{s 2}=75^{\circ}$ (Fig. 3-(e)-(f)), for both $\mathrm{CW}$ and PW as well as the total PF.

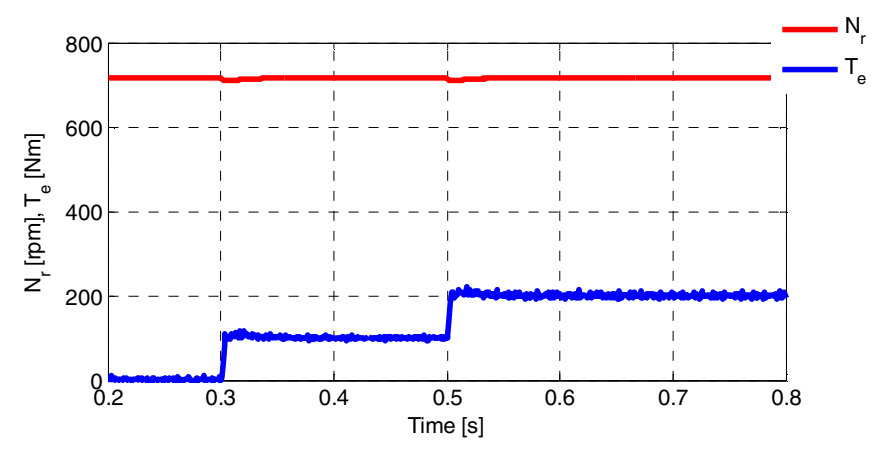

Fig. 2. Motor speed and torque curves. 


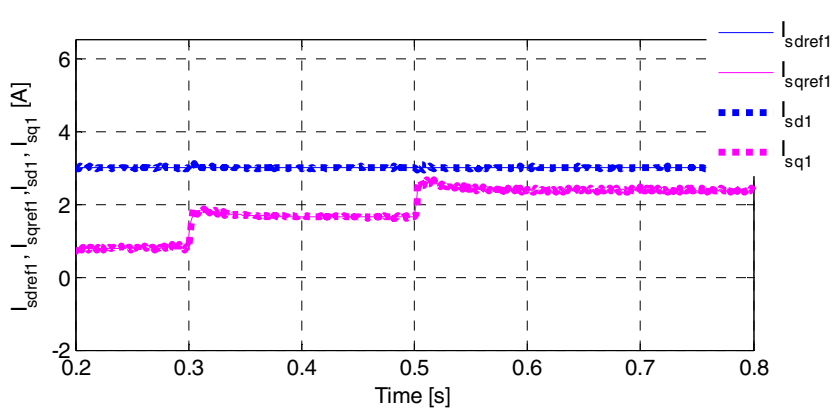

(a) Current components $I_{\text {sd } 1}$ and $I_{\text {sq1 } 1}$.

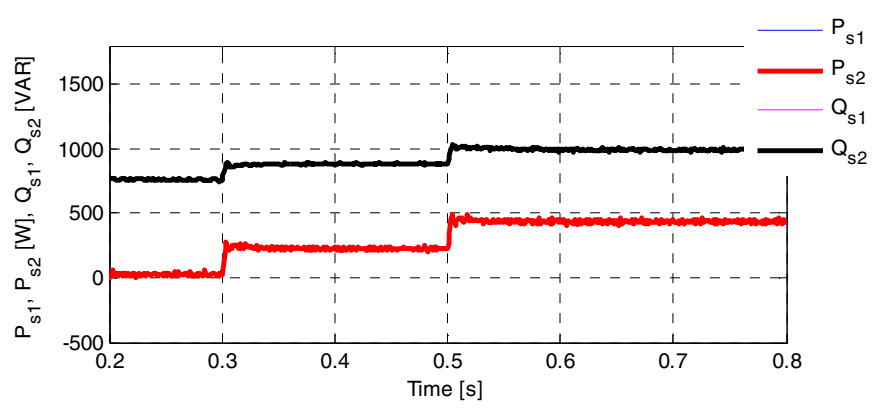

(c) Active and reactive powers $\mathrm{P}_{\mathrm{s}}$ and $\mathrm{Q}_{\mathrm{s}}$.

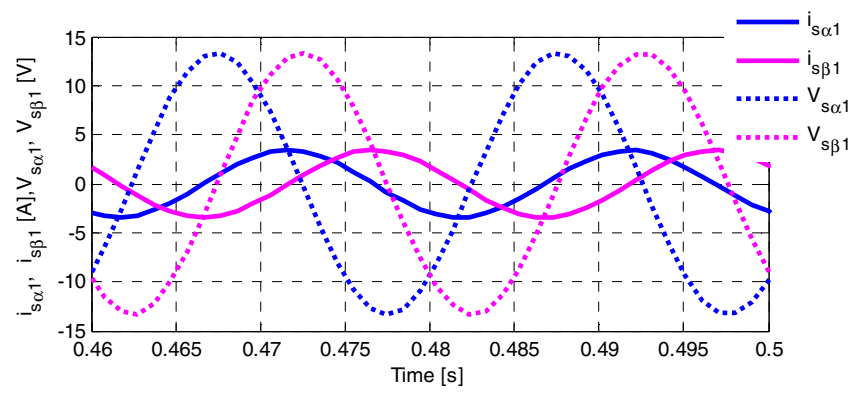

(e) Control winding $(\mathrm{CW})$ voltage and current components.

Fig. 3. Simulation results of IFOC of DSIM.

\section{b) PF correction with IFOC}

The PF presented in Fig. 3 is a low for both stator windings and this leads to additional power losses, especially inverter switching losses [6]. Furthermore, having two separate stator windings constitutes an additional freedom degree which can be used to manage the total power between those windings. Thereby, the $\mathrm{CW}$ is used to improve the PF of the $\mathrm{PW}$ and therefore the drive total efficiency. Accordingly, Fig. 4 shows the simulation results of PF correction with the new current references $I_{s d 2}=I_{s q 1}=0$ under the same IFOC control structure and simulation conditions as for the previous case. As a result, the main variables become $I_{s d 1}=6 \mathrm{~A}$ for the rotor

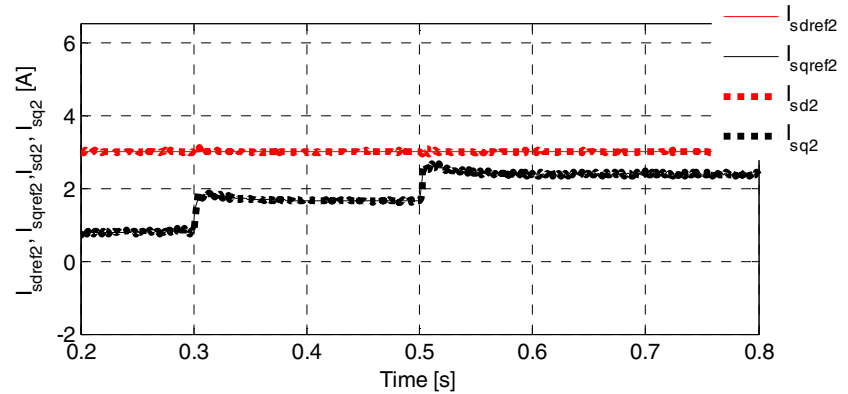

(b) Current components $\mathrm{I}_{\mathrm{sd} 2}$ and $\mathrm{I}_{\mathrm{sq} 2}$.

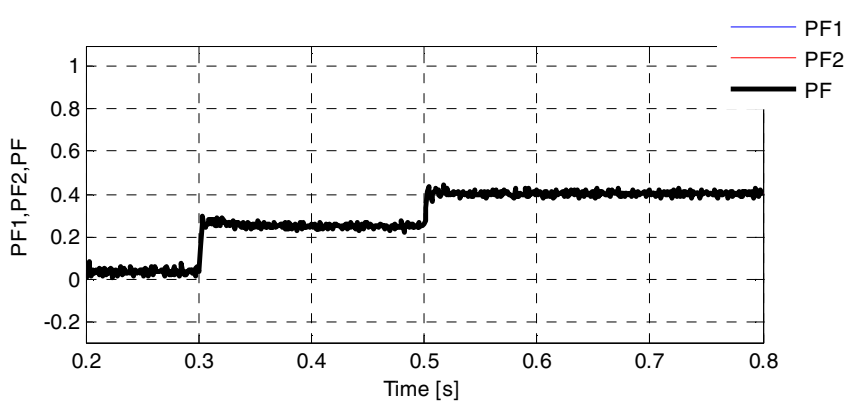

(d) PW, CW and total Power factors (PF).

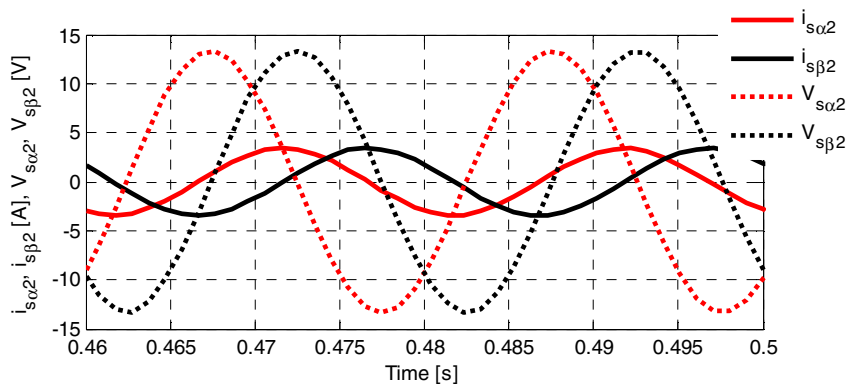

(f) Power winding (PW) voltage and current components.

flux, and $I_{s q 2}=3.3 \mathrm{~A}$ for the load torque (Fig. 4-(a)-(b)). Also, the active powers are $P_{s 1}=-320 \mathrm{~W}$ for the $\mathrm{CW}$ and $P_{s 2}=860 \mathrm{~W}$ for the $\mathrm{PW}$, as well the reactive powers are $Q_{s 1}=1540 \mathrm{VAR}$ for the CW and $Q_{s 2}=250 \mathrm{VAR}$ for the PW. So, it can be remarked that the $\mathrm{PW}$ practically supplies all the active power with a slight amount of reactive power and the $\mathrm{CW}$ provides the necessary reactive power. Consequently, the $\mathrm{PF}$ of the $\mathrm{PW}$ is forced to be equal to $P F_{2}=0.96$ in the vicinity of unity and different from that of the $\mathrm{CW}$ which is equal to $P F_{1}=-0.2$, whereas the total $P F$ is slightly improved and equal to $P F=0.285$. 


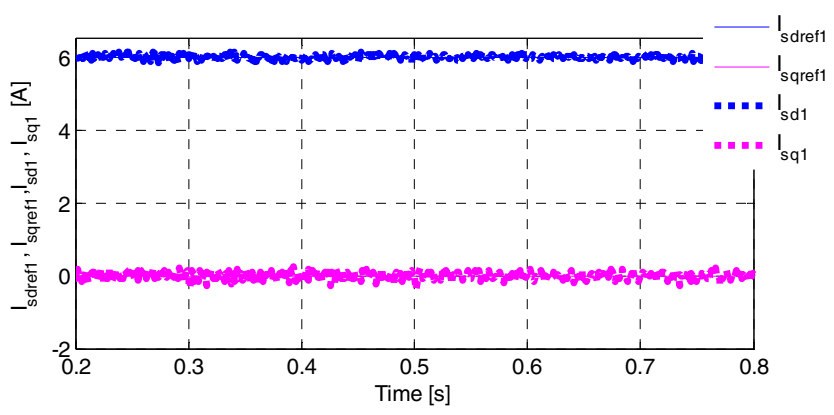

(a) Current components $I_{\mathrm{sd} 1}$ and $I_{\mathrm{sq} 1}$.

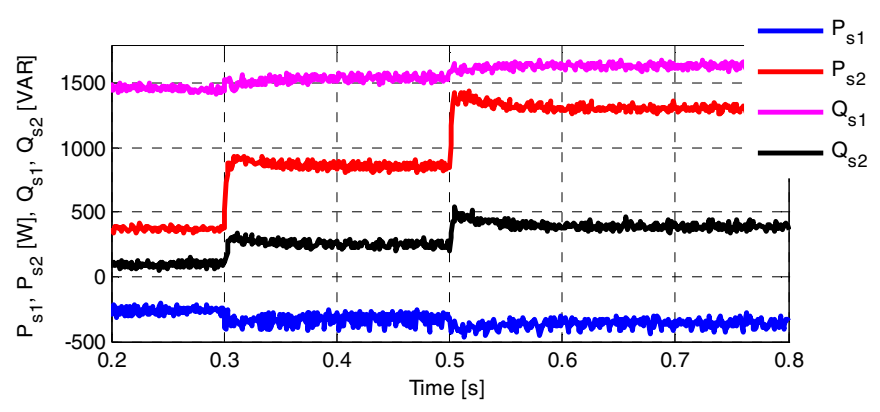

(c) Active and reactive powers $P_{s}$ and $Q_{s}$.

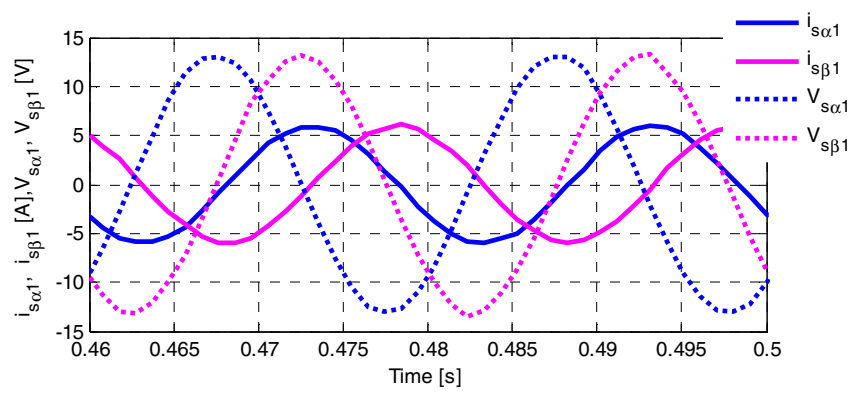

(e) Control winding $(\mathrm{CW})$ voltage and current components.

Fig. 4. Simulation results of PFC under IFOC.

\section{c) Active and reactive power control}

The new current references $\mathrm{I}_{\mathrm{sq} 1}$ and $\mathrm{I}_{\mathrm{sd} 2}$, calculated using (22), are introduced into the simulation program of the drive control scheme of Fig.1. Also, the nominal flux is maintained by the current component $I_{s d 1}=6 \mathrm{~A}$, while the other variables become $I_{s q 2}=2.1 \mathrm{~A}$ for the load torque, $I_{s q 1}=1.2 \mathrm{~A}$ and $I_{s d 2}=-0.6 A$ for the new power control current references (Fig. 5-(a)-(b)). Hence, the main active and reactive power components are $P_{s 2}=520 \mathrm{~W}$ for the $\mathrm{PW}$ and $Q_{s 1}=$ $1520 V A R$ for the $\mathrm{CW}$, respectively, whereas the extra power components $P_{s 1}$ and $Q_{s 2}$ are concealed (Fig. 5-(c)). Consequently, as shown in Fig. 5-(e) and (f) the CW load angle is kept $\varphi_{s 1}=90^{\circ}$ equivalent to $P F_{1}=0$ and the $\mathrm{PW}$ load angle is forced to be $\varphi_{s 2}=0^{\circ}$ allowing unity $P F$ with $P F_{2}=1$, moreover the total drive $P F$ equals 0.32 demonstrating an improvement ratio of $7 \%$.

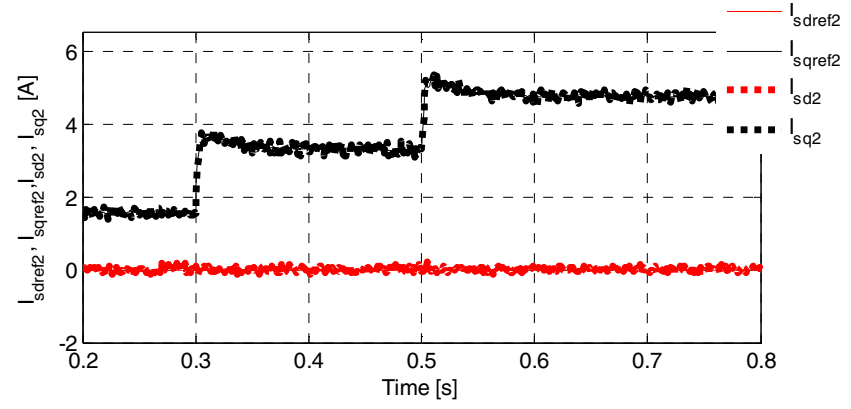

(b) Current components $\mathrm{I}_{\mathrm{sd} 2}$ and $\mathrm{I}_{\mathrm{sq} 2}$.

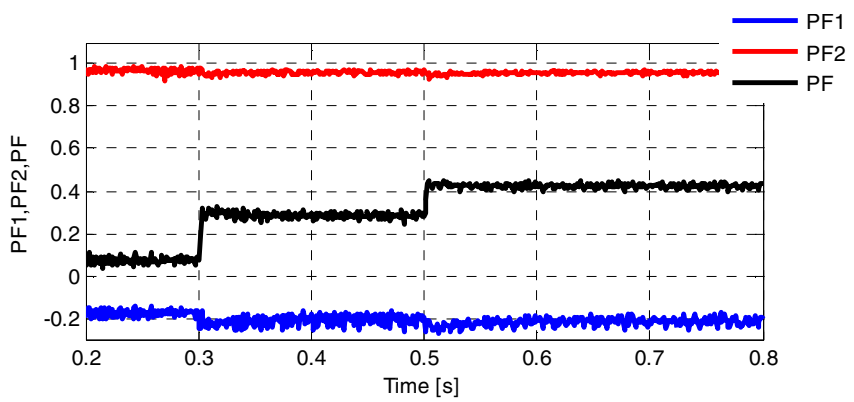

(d) PW, CW and total Power factor (PF).

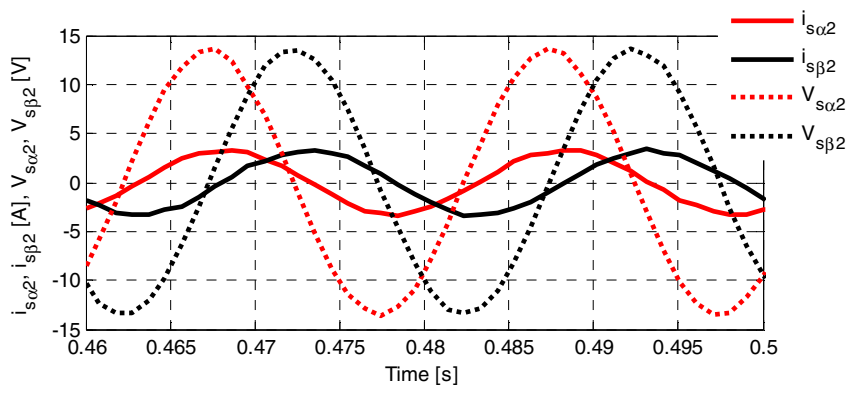

(f) Power winding (PW) voltage and current components.

\section{CONCLUSION}

In this paper the principle of PF correction in multiphase machines is presented and applied to a DSIM operating under IFOC. Simulation results are shown a successful decoupled power control and the PF of the PW is maintained equal to unity whatever the drive operating point with a significant improvement of the total drive PF.

This scheme is suitable for as most of drive systems based on multiphase machines dedicated to variable-speed and variable-load operations, and consequently to PF variation. While the aim of this paper is only to introduce the possibility of $\mathrm{PF}$ correction principle in multiphase machines under IFOC, switching losses evaluation is under studies and will be reported in a subsequent paper. 


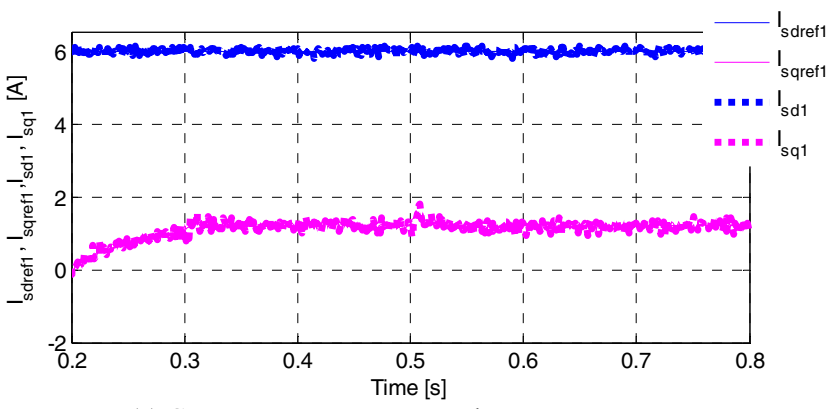

(a) Current components $I_{\mathrm{sd} 1}$ and $\mathrm{I}_{\mathrm{sq} 1}$.

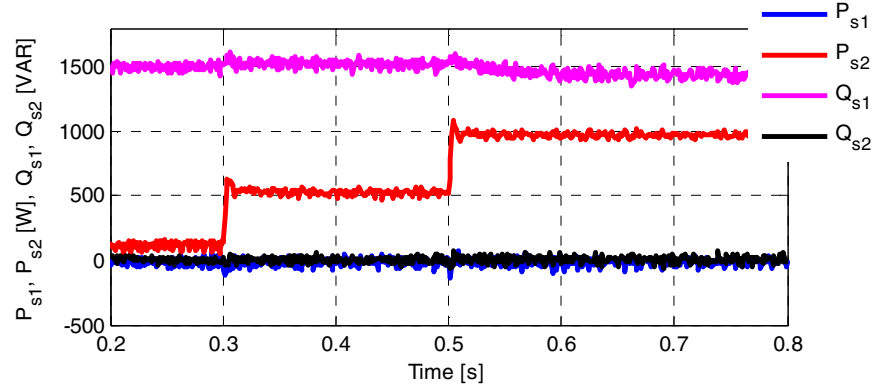

(c) Active and reactive powers $\mathrm{P}_{\mathrm{s}}$ and $\mathrm{Q}_{\mathrm{s}}$.

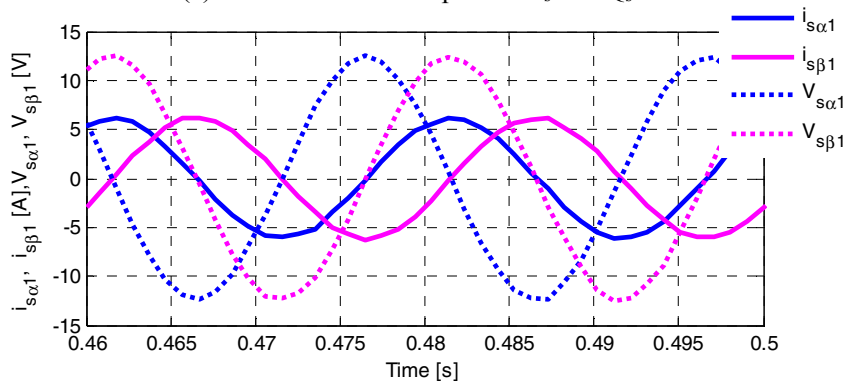

(e) Control winding $(\mathrm{CW})$ voltage and current components.

Fig. 5. Simulation results of PFC under active and reactive power control.

\section{APPENDIX}

TABLE I: Double Star Induction Machine parameters

\begin{tabular}{lc}
\hline \hline \multicolumn{1}{c}{ Quantity } & Symbol and magnitude \\
\hline Rated Power & $\mathrm{P}_{\mathrm{n}}=5.5 \mathrm{~kW}$ \\
Rated voltage & $\mathrm{V}_{\mathrm{n}}=220 \mathrm{~V}$ \\
Rated current & $\mathrm{I}_{\mathrm{n}}=6 \mathrm{~A}$ \\
Rated speed & $\mathrm{N}_{\mathrm{n}}=950 \mathrm{rpm}$ \\
Number of poles & $2 * \mathrm{p}=6$ \\
Rated Frequency & $\mathrm{f}=50 \mathrm{~Hz}$ \\
Stator resistance & $\mathrm{R}_{\mathrm{s}}=2.03 \Omega$ \\
Rotor resistance & $\mathrm{R}_{\mathrm{r}}=3 \Omega$ \\
Stator inductance & $\mathrm{L}_{\mathrm{s}}=0.215 \mathrm{H}$ \\
Rotor inductance & $\mathrm{L}_{\mathrm{r}}=0.215 \mathrm{H}$ \\
Mutual inductance & $\mathrm{M}=0.2 \mathrm{H}$ \\
Moment of inertia & $\mathrm{J}=0.06 \mathrm{~kg} \cdot \mathrm{m} 2$ \\
Coefficient of viscous friction & $\mathrm{k}_{\mathrm{f}}=0.006 \mathrm{~N} \cdot \mathrm{m} . \mathrm{s} / \mathrm{rad}$ \\
\hline \hline
\end{tabular}

\section{REFERENCES}

[1] E. Levi, "Multiphase electric machines for variable-speed applications," IEEE Trans. Ind. Electron., vol. 55, no. 5, pp.1893-1909, May 2008.

[2] K.Marouani, Lotfi Baghli, D. Hadiouche, A. Kheloui and A.Rezzoug, "A New PWM Strategy Based on a 24-Sector Vector Space Decomposition for a Six-Phase VSI-Fed Dual Stator Induction Motor," IEEE Trans. Ind. Electron., vol. 55, no. 5, pp.1910-1920, May 2008.

[3] F. Bu, Y. Hu, W. Huang, S. Zhuang and K. Shi, "Control Strategy and Dynamic Performance of Dual Stator-Winding Induction Generator

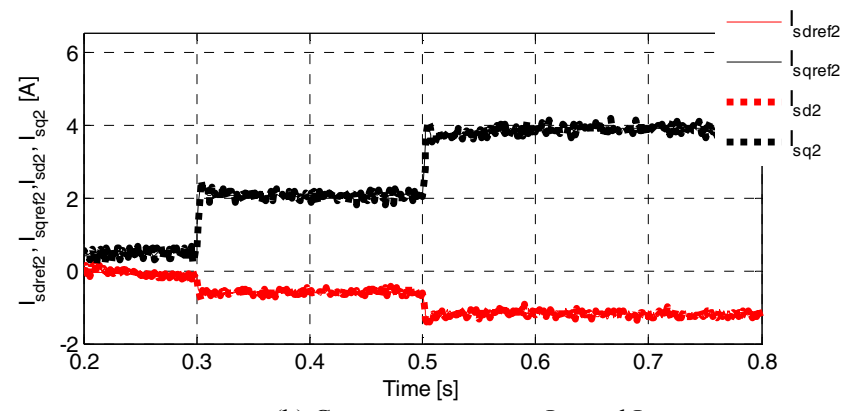

(b) Current components $\mathrm{I}_{\mathrm{sd} 2}$ and $\mathrm{I}_{\mathrm{sq} 2}$.

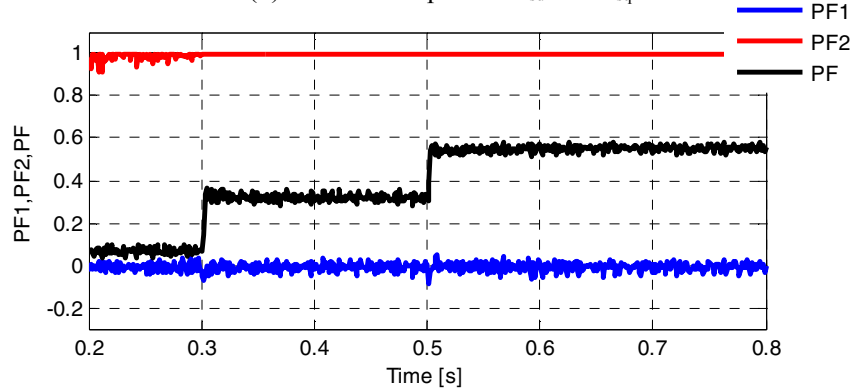

(d) PW, CW and total Power factor (PF).

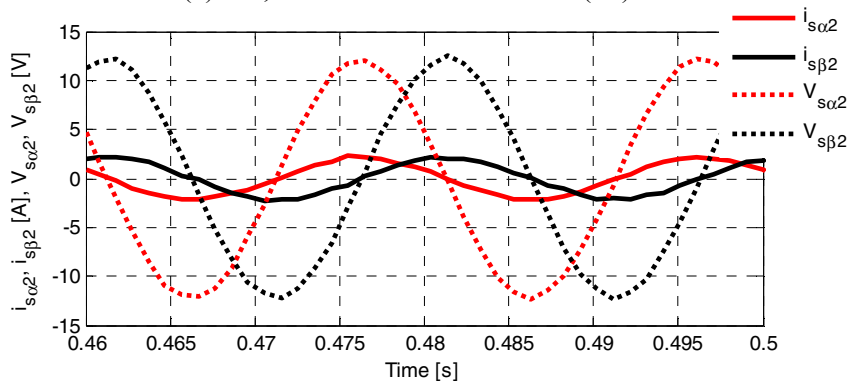

(f) Power winding (PW) voltage and current components.

Variable Frequency AC Generating System With Inductive and Capacitive Loads," IEEE Trans. Power Electron., vol. 29, no. 4, pp. 1681-1692, Apr. 2014.

[4] M. Bierhoff, H. Brandenburg and F. W. Fuchs, "An Analysis on Switching Loss Optimized PWM Strategies for Three Phase PWM Voltage Source Converters," The 33rd Annual Conference of the IEEE Industrial Electronics Society (IECON), Taipei, Taiwan, 2007.

[5] J. Rieto, M. Jones, F. Barrero E. Levi and S. Toral, "Comparative analysis of discontinuous and continuous PWM techniques in VSI-fed five-phase induction motor," IEEE Trans. Ind. Electron., vol. 58, no. 12, pp. 5324-5335, Dec. 2011

[6] Y. Wu, M. A. Shafi, A. M. Knight and R. A. Mcmahon, "Comparison of the effects of continuous and discontinuous PWM schemes on power losses of voltage-sourced inverters for induction motor drives," IEEE Trans. Power Electron., vol. 26 no. 1, pp. 182-191, Jan. 2011.

[7] N. V. Nguyen, B. X. Nguyen and H. H. Lee, "An optimized discontinuous PWM method to minimize switching loss for multilevel inverters," IEEE Trans. on Ind. Electron., vol. 58, no 9, pp. 3958-3966, Sep. 2011.

[8] E. Muljadi, T. A. Lipo and D. W. Novotny, "Power factor enhancement of induction machines by means of solid-state excitation," IEEE Trans. on Pow. Electron., vol. 4, no 4, pp. 409-418, Oct. 1989.

[9] C. Deng, L. Zhibin and Ye Pengsheng, "Power factor correction of a 400 $\mathrm{kW}$ winding rotor induction motor," The Fifth International Conference on Power Electronics and Drive Systems (IEEE-PEDS), 2003.

[10] K. Marouani, L. Bekrar, B. Tabbache, F. Khoucha and A. Kheloui, "Independent Control of a Two-Motor Drive System Fed by a Single Voltage Source Inverter," IFAC Power Plant and Power System Control Symposium (PPPSC), Toulouse, France, 2012.

[11] P. Vas, "Sensorless vector and direct torque control," Ed. Oxford University Press, 1998. 